\title{
Medya Okuryazarlığı Araştırmalarında Eğilimler: Lisansüstü Tezlere Yönelik Bir İçerik Analizi*
}

\section{Trends in Media Literacy Research: A Content Analysis of Postgraduate Dissertations}

\author{
Cahit ERDEM ${ }^{* *}$
}

\begin{abstract}
Received: 05 February 2018
\end{abstract}
Research Article

Accepted: 16 July 2018

ABSTRACT: This research aims to review postgraduate dissertations in media literacy field. To this end, 65 postgraduate dissertations that were completed between 2007-2017 in Turkey and that are accessible were reviewed with respect to completion year, university, department, topic, method, design, data collection technique, data analysis technique, sampling method and sample type variables. This is a qualitative, descriptive literature review study and document analysis was used to collect data via a dissertation review form. In the data analysis, content analysis method was used and percentages and frequencies were calculated for each category. The research results reveal that the highest number of dissertations was completed in 2013, only one dissertation was completed in 18 universities, the highest number of dissertations was carried out in journalism and radio TV and cinema departments; however, when departments related to educational sciences are combined, the highest number of dissertations were carried out in these departments, the most investigated topics are identification of the effects of media literacy education and participants' levels of media literacy, while quantitative methods are mostly used in dissertations, mixed methods are the least resorted, and the most addressed sample type includes secondary school students and prospective teachers follow them. This study aims to identify research trends in media literacy and guide future studies.

Keywords: media literacy dissertations, research trends, systematic review.

ÖZ: Bu araştırma medya okuryazarlığı alanında tamamlanmış olan lisansüstü tezlerin incelenmesini amaçlamaktadır. Bu amaçla, 2007-2017 yılları arasında tamamlanmış ve erişime açık olan lisansüstü tezler yıl, üniversite, bilim dalı, konu, yöntem, desen, veri toplama tekniği, veri analiz tekniği, örnekleme yöntemi ve örneklem türü değişkenleri açısından incelenmiştir. Nitel, betimsel bir literatür taraması olan bu araştırmada veri toplama yöntemi olarak doküman incelemesine başvurulmuştur. 65 lisansüstü tezden verilerin toplanması için araştırmacı tarafindan oluşturulan bir tez inceleme formu kullanılmıştır. Toplanan veriler içerik analizi yoluyla analiz edilmiş ve oluşturulan her bir kategori için yüzde ve frekans hesaplamaları yapılmıştır. Araştırma sonuçlarına göre medya okuryazarlığ alanında en çok sayıda tezin 2013 yılında tamamlandığı, 18 üniversitede sadece birer tez tamamlandığı, en fazla tezin gazetecilik ve radyo TV ve sinema bölümlerinde yapıldığı ancak eğitim bilimleri ile ilgili bölümler bir arada değerlendirildiğinde en çok tezin bu bölümlerde gerçekleştirildiği, tezlerin en çok medya okuryazarlığı eğitiminin etkisini belirleme ve medya okuryazarlığı düzeyi belirleme konularında gerçekleştirildiği, tezlerde en çok nicel yöntemlerin kullanıldığı, karma yöntemlerin ise çok az oranda işe koşulduğu, en sık başvurulan örneklem türünün ortaokul öğrencileri olduğu ve onları öğretmen adaylarının takip ettiği bulgularına ulaşılmıştır. Araştırmada medya okuryazarlığı alanındaki araştırma eğilimleri belirlenerek yeni yapılacak çalışmalara yol gösterici olmak hedeflenmiştir.

Anahtar kelimeler: medya okuryazarlığı tezleri, araştırma eğilimleri, sistematik inceleme.

\footnotetext{
* This study was first presented at I. International Education Research and Teacher Education Congress, 14-16 September 2017, Uşak, Turkey.

${ }^{* *}$ Corresponding Author: Dr., Afyon Kocatepe University, Afyonkarahisar, Turkey, cerdem@aku.edu.tr
}

Citation Information

Erdem, C. (2018). Trends in media literacy research: A content analysis of postgraduate dissertations. Kuramsal Eğitimbilim Dergisi [Journal of Theoretical Educational Science], 11(4), 693-717. 


\section{Giriş}

Yirmi birinci yüzyıl her alanda bireylerin hayatını dönüştürmüştür. Bilgi ve iletişim teknolojilerindeki hızlı gelişmeler bu durumun en temel nedenlerindendir (Kellner \& Share, 2007). Bu gelişmelerin neticesinde medya artık bir dijital balon içerisinde yaşayan insanların hayatının merkezine yerleşmiştir (Pérez Tornero \& Varis, 2010). Bireyler hayatının büyük bölümünde medya ile doğrudan etkileşim kurmanın yanısıra ikinci ve üçüncü düzeylerde de bu etkileşimi devam ettirmektedir (Masterman, 2005). Özellikle son dönemde yaşanan nispi ucuzlama ile yaygınlık kazanan ve daha kolay erişilebilen yeni medya araç ve uygulamaları (Erdem, 2018) nedeniyle bireyler yeni beceri ve yeterliklere ihtiyaç duymaktadır. Yirmi birinci yüzyıl becerileri olarak adlandırılan bu becerileri bireylerin edinmesi önemli bir gereklilik haline gelmiştir (Günüç, Odabaşı \& Kuzu, 2013). Bu becerilerin neler olduğuna dair yapılan birçok sınıflama olmakla beraber özellikle medyanın bireylerin hayatındaki yeri göz önüne alındığında ön plana çıkan yirmi birinci yüzyıl becerilerinden birisi medya okuryazarlı̆̆ıdır (Deveci \& Çengelci, 2008; Finegold \& Notabartolo, 2008).

Çeşitli medya mesajlarına erişme, onları analiz etme, değerlendirme ve iletme becerisi olarak tanımlanan medya okuryazarlığı (Aufderheide, 1993) güzel sanatlar ve performans sanatları, tarih, psikoloji, sosyoloji ve eğitim gibi farklı disiplinlerin çalışma alanına girmiştir (Hobbs, 1998) ve resmi eğitim ortamlarında uzun yıllardır devam eden uluslararası uygulamaların bir sonucu olarak oturmuş bir kavramsal temele sahiptir (Hobbs \& Frost, 2003). Türkiye'de ise medya okuryazarlığı çalışmaları diğer ülkelere göre gecikmeli olarak gündeme gelmiştir (Som \& Kurt, 2012). Türkiye'de bu çalışmalar 2000 yılından sonra başlamış (Önal, 2007), medya okuryazarlığının pilot uygulama çerçevesinde ilk olarak 2006-2007 öğretim yılında ortaokul düzeyinde seçmeli bir ders olarak eğitim programına dahil edilmesiyle hız kazanmıştır. 2007-2008 öğretim yılı itibariyle ortaokul düzeyinde seçmeli bir ders olarak okutulmaya başlanan medya okuryazarlığı dersinin öğretim programı 2013 yılında değiştirilerek medya okuryazarlığı eğitiminde medya aracı temelli bir anlayıştan medya okuryazarlığı becerileri temelli bir anlayışa geçilmiştir. Sadece 2007-2012 yılları arasında üç milyondan fazla öğrenci bu dersi almıştır. Bu süreçte öğretmenler için sınırlı düzeyde hizmet içi eğitimler düzenlenmiş (Erdem, 2018) ve eğitim bilimleri, iletişim bilimleri ve güzel sanatlar gibi alanlarda medya okuryazarlığ çalışmaları ve araştırmaları yapılmıştır.

Türkiye'de medya okuryazarlığı konusundaki yayınlarda sürekli bir artış yaşanmaktadır ve bu alandaki makale, bildiri ve tezlerin sayısının fazla olması konuya olan akademik ilginin arttığını göstermektedir (Altun, 2014). Medya okuryazarlığı alanındaki bu akademik birikimlerin belirli aralıklarla incelenmesi, çalışma eğilimlerinin belirlenmesi önem taşır. Bir yandan bilimsel alanda politika ve uygulamaları etkileyen diğer yandan da uygulayıcılar için bir rehber işlevi gören bilimsel çalışmalar (Karadağ, 2009) diğer bilimsel çalışmalara dayalı olarak ilerlediğinden, bu bilimsel çalışmaların incelenmesi gerekmektedir (Gülbahar \& Alper, 2009). Bir alandaki bilimsel çalışmaların özelliklerinin incelenmesi ve o alandaki araştırma eğilimlerinin belirlenmesi değişim ve gelişimlerin izlenmesini mümkün kılar (Yıldız, Melekoğlu \& Paftalı, 2016). Bu nedenle, medya okuryazarlığı alanında yapılan çalışmaların özelliklerinin incelenmesi ve eğilimlerin belirlenmesi medya okuryazarlığ alanına 1şık tutacak ve yeni çalışmalar için yol gösterici olacaktır. 
Medya okuryazarlığı alanındaki çalışmaları inceleyen farklı araştırmalar mevcuttur. Bu kapsamda, Altun (2014) medya okuryazarlığı alanındaki bütün yayınların bibliyografyasını çıkarmıştır. Kıncal \& Korkmaz (2015) ise medya okuryazarlığı alanında yayınlanan makaleleri incelemiştir. Son olarak Maden, Maden \& Banaz (2017) medya okuryazarlığı alanında yapılan lisansüstü tezleri amaç, yıl ve sonuç açılarından incelemiştir. Medya okuryazarlığı alanında ilk lisansüstü tez 2007 yılında tamamlanmıştır ve geçen on yıllık süreçte 65 lisansüstü tez tamamlanmıştır. Kısa sürede bu sayıda lisansüstü araştırmanın yapılması bu çalışmaları daha detaylı ve farklı değişkenleri içeren bir incelemeye tabi tutma gereğini ortaya çıkarmıştır. Bu yönde yapılacak bir çalışmanın medya okuryazarlığı alanındaki çalışmaların özelliklerini ortaya koyması, araştırma eğilimlerini belirlemesi ve yeni yapılacak çalışmalara yol göstermesi beklenmektedir.

$\mathrm{Bu}$ araştırmada, Türkiye'de medya okuryazarlığı alanında yapılmış olan lisansüstü tezlerin incelenmesi amaçlanmaktadır. Bu temel amaç doğrultusunda tezlerin özelliklerini ve araştırma eğilimlerini belirlemek için yanıtı aranan sorular şunlardır:

1. Medya okuryazarlığı alanında yapılmış olan lisansüstü tezlerin yıllara göre dağılımı nasıldir?

2. Medya okuryazarlığg alanında yapılmış olan lisansüstü tezlerin üniversitelere göre dağılımı nasıldır?

3.Medya okuryazarlığ 1 alanında yapılmış olan lisansüstü tezlerin bilim dallarına göre dağılımı nasıldır?

4. Medya okuryazarlığı alanında yapılmış olan lisansüstü tezlerin konulara göre dağılımı nasıldır?

5. Medya okuryazarlığı alanında yapılmış olan lisansüstü tezlerin yönteme ve desene göre dağılımı nasıldır?

6. Medya okuryazarlığı alanında yapılmış olan lisansüstü tezlerin veri toplama tekniğine göre dağılımı nasıldır?

7. Medya okuryazarlığı alanında yapılmış olan lisansüstü tezlerin veri analiz tekniklerine göre dağılımı nasıldır?

8. Medya okuryazarlığı alanında yapılmış olan lisansüstü tezlerin örnekleme yöntemine göre dağılımı nasıldır?

9. Medya okuryazarlığı alanında yapılmış olan lisansüstü tezlerin örneklem türüne göre dağılımı nasıldır?

\section{Yöntem}

Medya okuryazarlığı alanında yapılan lisansüstü tezlerin incelenmesini amaçlayan bu araştırma alanyazın taramasına bağlı betimsel bir araştırmadır. Literatür taraması araştırmaları yayınlanmış olan çalışmaların değerlendirilmesini içerir (APA, 2010). Araştırmada veri toplama yöntemi olarak doküman incelemesi yöntemine başvurulmuştur. Doküman incelemesi resmi yayınlar, raporlar, kayıtlar, anket ve taramalara açık uçlu cevaplar gibi yazılı materyallerin analizini içerir (Patton, 2002). Bu araştırmada doküman incelemesi yöntemi yoluyla medya okuryazarlığı alanında tamamlanmış olan lisansüstü tezler analiz edilmiştir. 


\section{Örneklem}

$\mathrm{Bu}$ çalışmanın örneklemi Temmuz 2017 itibariyle Türkiye'de medya okuryazarlığı konusunda yapılmış ve erişime açık olan lisansüstü tezlerden oluşmaktadır. Yükseköğretim Kurulu Başkanlığı Tez Merkezi'nden medya okuryazarlığ1 anahtar kelimeleri kullanılarak sorgulama yapılmış ve medya okuryazarlığı ile ilgili 65 lisansüstü teze ulaşılmıştır. Bu tezlerden 12 tanesi erişime kapalı olduğu için bu tezler sadece düzey, yıl, üniversite, bilim dalı gibi erişime açık bilgiler üzerinden analize dahil edilmiştir. Araştırmanın örneklemi ${ }^{1}$ erişime açık olan 39 yüksek lisans tezinden ve 14 doktora tezinden oluşmaktadır.

\section{Veri Toplama Aracı}

Doküman incelemesi yöntemiyle toplanan verilerin toplanma sürecinde araştırmacı tarafından geliştirilen bir tez inceleme formu kullanılmıştır. Bu form tezin tamamlanma tarihi, yapıldığı üniversite, bilim dalı, konu alanı, yöntem, desen, veri toplama tekniği, veri toplama aracı, veri analiz teknikleri, örnekleme yöntemi ve örneklem türü kategorilerinden oluşmaktadır. Form oluşturulurken alandaki benzer literatür taraması araştırmalarından faydalanılmıştır.

\section{Verilerin Analizi}

Verilerin analizinde içerik analizi yöntemine başvurulmuştur. Doküman analizi yöntemiyle toplanan ve tez inceleme formu yoluyla kodlanan veriler içerik analizi tekniği ile analiz edilmiştir. Kelimelerin, ifadelerin ya da temaların/kategorilerin sayılmasını içeren ve bir dokümanın özelliklerinin belirlenmesini amaçlayan içerik analizi sistematik ve objektif bir yöntemdir (Bloor \& Wood, 2006). Oluşturulan her bir kategori için yüzde ve frekans hesaplamaları yapılmıştır. Verilerin kodlanması ve temalara aktarılması sürecinde tutarlılığı sağlamak için benzer içerik analizi çalışmaları yürütmüş ikinci bir araştırmacıdan yardım alınmış, analizin uygunluğu değerlendirilmiş ve gerekli değişiklikler yapılan tartışmalara dayalı olarak gerçekleştirilmiştir. Ek olarak, incelenen tezlerin Yükseköğretim Kurulu Tez Merkezi aracılığı ile bütün araştırmacılar için erişilebilir olması da araştırmanın geçerliği için önemli bir durumdur. Tez inceleme formu doldurulurken ilgili tezlerde yer verilen bilgiler kullanılmış, aranan bilgilerin bulunmadığı durumlarda 'belirtilmemiş' seçeneği kullanılmıştır. Konu alanlarına karar verirken ilgili tezin başlı̆̆ı, anahtar kelimeleri ve araştırma amaçları bir arada değerlendirilmiştir.

\footnotetext{
1 Aktı, 2011; Altun, 2010; Apak, 2008; Ardıç, 2016; Aslan, 2009; Aydemir, 2013; Bacaksız, 2010; Bakan, 2010; Baş, 2015; Bilici, 2011; Bütün, 2010; Çakmak, 2010; Çelik, 2008; Çelik, 2011; Çetinkaya, 2008; Çiçek, 2013; Çinelioğlu, 2013; Ertek, 2013; Görmez, 2014; Güner, 2011; İlhan, 2014; İnan, 2010, 2013; Karakoç, 2011; Karataş, 2008; Kartal, 2007,2013; Keleş, 20090; Keleş, 2013; Koçak, 2011; Oflaz, 2016; Oktay, 2013; Sadriu, 2009;Semiz, 2013; Sezen, 2011; Sevim, 2013; Solmaz, 2016; Söylemez, 2012; Sur, 2012; Şahin, 2012; Şeylan, 2008; Tan, 2015; Tanrıkulu, 2014; Tatar, 2016; Tuncel, 2014; Tutkun, 2013; Tüzel, 2012; Ülker, 2012; Yazgan, 2013; Yıldırım Ankaralıgil, 2009; Yıldız, 2011; Y1lmaz, 2013; Yördem, 2012
} 


\section{Bulgular}

$\mathrm{Bu}$ bölümde elde edilen bulgular araştırma soruları ile uyumlu olarak açıklanmıştır.

\section{Medya Okuryazarlığı Alanında Yapılmış Olan Lisansüstü Tezlerin Yıllara Göre Dağılımına İlişkin Bulgular}

Birinci araştırma sorusu kapsamında medya okuryazarlığı alanında yapılmış olan lisansüstü tezlerin yıllara göre dağılımı Tablo 1'de sunulmuştur.

Tablo 1

Lisansüstü Tezlerin Yıllara Göre Dă̆glımı

\begin{tabular}{lcccccc}
\hline \multirow{2}{*}{ Y11 } & \multicolumn{2}{c}{ Yüksek lisans } & \multicolumn{2}{c}{ Doktora } & \multicolumn{2}{c}{ Toplam } \\
\cline { 2 - 7 } & $f$ & $\%$ & $F$ & $\%$ & $f$ & $\%$ \\
2007 & 1 & 2.2 & 0 & 0 & 1 & 1.5 \\
2008 & 4 & 8.3 & 1 & 5.7 & 5 & 7.7 \\
2010 & 4 & 8.3 & 0 & 0 & 4 & 6.2 \\
2011 & 4 & 8.3 & 2 & 11.8 & 6 & 9.2 \\
2012 & 5 & 10.4 & 2 & 11.8 & 7 & 10.8 \\
2013 & 5 & 10.4 & 2 & 11.8 & 7 & 10.8 \\
2014 & 9 & 18.8 & 4 & 23.5 & 13 & 20 \\
2015 & 5 & 10.4 & 2 & 11.8 & 7 & 10.8 \\
2016 & 6 & 12.5 & 2 & 11.8 & 8 & 12.3 \\
\hline Toplam & 5 & 10.4 & 2 & 11.8 & 7 & 10.8 \\
\hline
\end{tabular}

Medya okuryazarlığı alanında ilk tezin 2007 yılında tamamlandığ görülmektedir. Yıllar içerisinde tez sayısında önemli artışlar olmuştur ve 48 yüksek lisans, 17 doktora tezi olmak üzere toplamda 65 tez tamamlanmıştır. En çok sayıda tezin 2013 yılında tamamlandığı görülmektedir (\%20).

\section{Medya Okuryazarlığı Alanında Yapılmış Olan Lisansüstü Tezlerin} Üniversitelere Göre Dağılımına İlişkin Bulgular

Araştırmanın ikinci sorusu lisansüstü tezlerin gerçekleştirildiği üniversitelere ilişkindir. Lisansüstü tezlerin yürütüldüğü üniversitelere göre dağılımı Tablo 2’de sunulmuştur. 
Tablo 2

Lisansüstü Tezlerin Üniversitelere Göre Dă̆ılımı

\begin{tabular}{|c|c|c|c|c|c|c|}
\hline \multirow[t]{2}{*}{ Üniversite } & \multicolumn{2}{|c|}{ Yüksek lisans } & \multicolumn{2}{|c|}{ Doktora } & \multicolumn{2}{|c|}{ Toplam } \\
\hline & $f$ & $\%$ & $f$ & $\%$ & $f$ & $\%$ \\
\hline Adnan Menderes Ü. & 1 & 2.1 & 0 & 0 & 1 & 1.5 \\
\hline Afyon Kocatepe Ü. & 1 & 2.1 & 0 & 0 & 1 & 1.5 \\
\hline Akdeniz Ü. & 0 & 0 & 1 & 5.9 & 1 & 1.5 \\
\hline Ankara Ü. & 1 & 2.1 & 0 & 0 & 1 & 1.5 \\
\hline Balıkesir Ü. & 1 & 2.1 & 0 & 0 & 1 & 1.5 \\
\hline Ege Ü. & 1 & 2.1 & 0 & 0 & 1 & 1.5 \\
\hline Eskişehir Osmangazi Ü. & 1 & 2.1 & 0 & 0 & 1 & 1.5 \\
\hline Firat Ü. & 1 & 2.1 & 0 & 0 & 1 & 1.5 \\
\hline İstanbul Kültür Ü. & 1 & 2.1 & 0 & 0 & 1 & 1.5 \\
\hline İstanbul Ticaret Ü. & 1 & 2.1 & 0 & 0 & 1 & 1.5 \\
\hline Kadir Has Ü. & 1 & 2.1 & 0 & 0 & 1 & 1.5 \\
\hline Maltepe Ü. & 0 & 0 & 1 & 5.9 & 1 & 1.5 \\
\hline Muğla Sttkı Koçman Ü. & 1 & 2.1 & 0 & 0 & 1 & 1.5 \\
\hline Niğde Ü. & 1 & 2.1 & 0 & 0 & 1 & 1.5 \\
\hline Pamukkale Ü. & 1 & 2.1 & 0 & 0 & 1 & 1.5 \\
\hline R. Tayyip Erdoğan Ü. & 1 & 2.1 & 0 & 0 & 1 & 1.5 \\
\hline Süleyman Demirel Ü. & 1 & 2.1 & 0 & 0 & 1 & 1.5 \\
\hline Yaşar Ü. & 1 & 2.1 & 0 & 0 & 1 & 1.5 \\
\hline Selçuk Ü. & 2 & 4.2 & 0 & 0 & 2 & 3.1 \\
\hline Dumlupınar Ü. & 1 & 2.1 & 1 & 5.9 & 2 & 3.1 \\
\hline Erciyes Ü. & 1 & 2.1 & 1 & 5.9 & 2 & 3.1 \\
\hline A. İzzet Baysal Ü. & 2 & 4.2 & 1 & 5.9 & 3 & 4.7 \\
\hline Anadolu Ü. & 2 & 4.2 & 1 & 5.9 & 3 & 4.7 \\
\hline İstanbul Ü. & 2 & 4.2 & 1 & 5.9 & 3 & 4.7 \\
\hline Kocaeli Ü. & 3 & 6.2 & 0 & 0 & 3 & 4.7 \\
\hline Ondokuz Mayıs Ü. & 3 & 6.2 & 0 & 0 & 3 & 4.7 \\
\hline Marmara Ü. & 3 & 6.2 & 1 & 5.9 & 4 & 6.2 \\
\hline Atatürk Ü. & 6 & 12.5 & 1 & 5.9 & 7 & 10.8 \\
\hline Gazi Ü. & 4 & 8.1 & 3 & 17.6 & 7 & 10.8 \\
\hline Ç. Onsekiz Mart Ü. & 3 & 6.2 & 5 & 29.3 & 8 & 12.4 \\
\hline Toplam & 48 & 100 & 17 & 100 & 65 & 100 \\
\hline
\end{tabular}

Tablo 2'de görüldügü üzere 18 üniversitede sadece birer tez tamamlanmıştır ve bu tezlerin sadece iki tanesi doktora tezidir. En çok sayıda tezin ise Çanakkale Onsekiz 
Mart Üniversitesi’nde (\%12.3) tamamlandığı, bu üniversiteyi Gazi Üniversitesi (\%10.8) ve Atatürk Üniversitesi'nin (\%10.8) takip ettiği görülmektedir. Düzeylere göre bakıldığında ise en çok sayıda yüksek lisans tezi Atatürk Üniversitesi'nde (\%12.5) ve en çok sayıda doktora tezi Çanakkale Onsekiz Mart Üniversitesi’nde (\%29.4) tamamlanmıştır.

\section{Medya Okuryazarlığı Alanında Yapılmış Olan Lisansüstü Tezlerin Bilim Dallarına Göre Dağılımına İlişskin Bulgular}

Araştırmanın üçüncü sorusu olan lisansüstü tezlerin yürütüldüğü bilim dallarına göre dağılımı Tablo 3'te verilmiştir. Bilim dallarının farklı üniversitelerde farklı şekilde isimlendirildiği durumlarda birbirine en yakın bilim dalları birlikte değerlendirilmiştir.

Tablo 3

Lisansüstü Tezlerin Bilim Dallarına Göre Dă̆ılımı

\begin{tabular}{|c|c|c|c|c|c|c|}
\hline \multirow[t]{2}{*}{ Bilim dalı } & \multicolumn{2}{|c|}{ Yüksek lisans } & \multicolumn{2}{|c|}{ Doktora } & \multicolumn{2}{|c|}{ Toplam } \\
\hline & $f$ & $\%$ & $f$ & $\%$ & $f$ & $\%$ \\
\hline Basın ve yayın & 0 & 0 & 1 & 5.9 & 1 & 1.5 \\
\hline Eğitim teknolojisi & 0 & 0 & 1 & 5.9 & 1 & 1.5 \\
\hline $\begin{array}{l}\text { Güzel sanatlar } \\
\text { eğitimi }\end{array}$ & 1 & 2.1 & 0 & 0 & 1 & 1.5 \\
\hline $\begin{array}{l}\text { Halkla ilişkiler ve } \\
\text { tanıtım }\end{array}$ & 1 & 2.1 & 0 & 0 & 1 & 1.5 \\
\hline $\begin{array}{l}\text { İngilizce } \\
\text { öğretmenliği }\end{array}$ & 1 & 2.1 & 0 & 0 & 1 & 1.5 \\
\hline Kamu yönetimi & 1 & 2.1 & 0 & 0 & 1 & 1.5 \\
\hline $\begin{array}{l}\text { Medya ve iletişim } \\
\text { sistemleri }\end{array}$ & 1 & 2.1 & 0 & 0 & 1 & 1.5 \\
\hline Yeni medya & 1 & 2.1 & 0 & 0 & 1 & 1.5 \\
\hline $\begin{array}{l}\text { Bilgisayar ve Ö. T. } \\
\text { eğitimi }\end{array}$ & 2 & 4.2 & 0 & 0 & 2 & 3.1 \\
\hline Eğitim bilimleri & 1 & 2.1 & 3 & 17.7 & 4 & 6.3 \\
\hline İletişim & 2 & 4.2 & 2 & 11.7 & 4 & 6.3 \\
\hline Türkçe öğretmenliği & 2 & 4.2 & 2 & 11.7 & 4 & 6.3 \\
\hline $\begin{array}{l}\text { Eğitim programları } \\
\text { ve öğretim }\end{array}$ & 5 & 10.4 & 1 & 5.9 & 6 & 9.2 \\
\hline İlköğretim & 5 & 10.4 & 1 & 5.9 & 6 & 9.2 \\
\hline Sınıf öğretmenliği & 6 & 12.5 & 0 & 0 & 6 & 9.2 \\
\hline $\begin{array}{l}\text { Sosyal bilgiler } \\
\text { öğretmenliği }\end{array}$ & 4 & 8.2 & 2 & 11.7 & 6 & 9.2 \\
\hline Radyo tv ve sinema & 8 & 16.7 & 1 & 5.9 & 9 & 13.8 \\
\hline Gazetecilik & 7 & 14.5 & 3 & 17.7 & 10 & 15.4 \\
\hline
\end{tabular}


Tablo 3 incelendiğinde medya okuryazarlığı tezlerinin 17 farklı alanda gerçekleştirildiği, en fazla sayıda lisansüstü tezin ise gazetecilik (\%15.4) ve radyo, tv ve sinema (\%13.8) bilim dallarında gerçekleştirildiği görülmektedir. Diğer yandan, eğitim bilimleri ile ilişkili bölümler bir arada değerlendirildiğinde en çok sayıda lisansüstü tezin bu alanda yapıldığı söylenebilir (\%56.8). Eğitim ile ilgili alt alanlarda ise en çok sayıda tez sosyal bilgiler öğretmenliği, sınıf öğretmenliği, ilköğretim ve eğitim programları ve öğretim bölümlerinde yapılmıştır.

\section{Medya okuryazarlığı alanında yapılmış olan lisansüstü tezlerin konulara göre dağılımına ilişkin bulgular}

Araştırmanın dördüncü sorusu kapsamında lisansüstü tezlerin gerçekleştirildiği konulara göre dağılımı incelenmiş ve söz konusu dağılım Tablo 4'te sunulmuştur.

Tablo 4

Lisansüstü Tezlerin Konulara Göre Dă̆llımı

\begin{tabular}{|c|c|c|c|c|}
\hline Tema & Alt tema & Yüksek lisans & Doktora & Sayı \\
\hline \multirow{5}{*}{$\begin{array}{l}\text { Medya okuryazarlığg } \\
\text { düzey belirleme }\end{array}$} & Öğretmen adaylarının düzeyleri & M1, M10, M27 & & 10 \\
\hline & Öğretmenlerin düzeyleri & M28 & & \\
\hline & $\begin{array}{l}\text { Ortaokul öğrencilerinin } \\
\text { düzeyleri }\end{array}$ & M2, M23, M35, & D11, D13 & \\
\hline & Lise öğrencilerinin düzeyleri & M29 & & \\
\hline & Öğrenci velilerinin düzeyleri & & D13 & \\
\hline \multirow{3}{*}{$\begin{array}{l}\text { Medya okuryazarlığı } \\
\text { ve medya } \\
\text { okuryazarlığı dersine } \\
\text { ilişkin görüş ve } \\
\text { algıları belirleme }\end{array}$} & Öğretmen görüşleri & $\begin{array}{l}\text { M4, M9, M11, } \\
\text { M18 }\end{array}$ & D14 & 8 \\
\hline & Öğrenci Görüşleri & $\begin{array}{l}\text { M11, M14, M18, } \\
\text { M32, M39 }\end{array}$ & D14 & \\
\hline & Veli Görüşleri & M11 & D14 & \\
\hline \multirow{5}{*}{$\begin{array}{l}\text { Dünyadaki ve } \\
\text { Türkiye'deki medya } \\
\text { okuryazarlığı } \\
\text { eğitiminin } \\
\text { incelenmesi ve } \\
\text { karşılaştırılması }\end{array}$} & Öğretim programlarının & M5 & & 8 \\
\hline & karşılaştırılması & & & \\
\hline & $\begin{array}{l}\text { Türkiye ve farklı ülkelerdeki } \\
\text { MO eğitiminin karşılaştırılması }\end{array}$ & M6, M26 & $\begin{array}{l}\text { D3, D4, } \\
\text { D5 }\end{array}$ & \\
\hline & $\begin{array}{l}\text { MO öğretmen kılavuz kitabının } \\
\text { öğretim programı ile tutarlılı̆̆ }\end{array}$ & & D6 & \\
\hline & $\begin{array}{l}\text { Farklı ülkelerdeki MO tezlerinin } \\
\text { incelenmesi }\end{array}$ & M37 & & \\
\hline \multirow{5}{*}{$\begin{array}{l}\text { Medya } \\
\text { okuryazarlığının } \\
\text { başka bir değişkenle } \\
\text { ilişkisinin } \\
\text { belirlenmesi }\end{array}$} & Eleştirel düşünme & M8 & & 7 \\
\hline & Sosyal beceri düzeyi & M12 & & \\
\hline & $\begin{array}{l}\text { Gazete ve dergi takip etme } \\
\text { alışkanlıkları }\end{array}$ & M24 & & \\
\hline & Çevrimiçi bilgi arama stratejileri & M36 & & \\
\hline & $\begin{array}{l}\text { Toplum yaşamına katılma } \\
\text { düzeyi }\end{array}$ & & D7 & \\
\hline
\end{tabular}


Temsili demokrasiye, protesto

D9

ve sosyal değişime katılım

düzeyi

Demokratik değer düzeyi

D10

Medya okuryazarlığg eğitiminin etkisi
Medya okuryazarlığ ile ilişkili teorik çalışmalar
Medya okuryazarlığının başka bir dersle ilişkilendirilmesi
Medya mesajlarını algılamaya etki

Çok kültürlü bakış açısı geliştirmeye etki

Ahlaki gelişime etki

Eleştirel düşünmeye etki

Medya tüketim alışkanlığına etki

Medya-demokrasi ilişkisine etki

Medyaya bakış üzerindeki etki

Toplumsal cinsiyet

Yeni medyada imaj, görüntü ve beden sunumu

Yeni iletişim teknolojileri

bağlamında MO'nun

değerlendirilmesi

Eleştirel pedagoji bağlamında medya okuryazarlığ 1 dersi

Medya okuryazarlığının gerekliliği

Sanat eğitimi

Sosyal bilgiler

M7

Türkçe dersi

M31

M13

M16

M20

M30

M22

M33

M34
M3, M17, M21,

M19, M38

D1

4

D2

D8, D12

Medya okuryazarlığı tezlerinin çalıştığ1 konular sekiz ayrı kategoride gruplandırılmıştır. Bazı tezlerin birden fazla kategori ile ilişkili olduğu görülmüştür. Çalışılan konuların sıklığı incelendiğinde, en çok sayıda lisansüstü tezin medya okuryazarlığı eğitiminin çeşitli değişkenler üzerindeki etkisinin belirlenmesi üzerine olduğu görülmektedir (11). Bu konuyu medya okuryazarlığı düzey belirleme (10), görüş, alg1 ve tutumları belirleme (8) ve dünyadaki ve Türkiye'deki medya okuryazarlığı eğitiminin incelenmesi ve karşılaştırılması (8) konuları izlemiştir. En az çalışılan konuların ise medya okuryazarlığının başka bir dersle ilişkilendirilmesi (4) konularının olduğu belirlenmiştir.

\section{Medya Okuryazarlığı Alanında Yapılmış Olan Lisansüstü Tezlerin Yöntem Ve Desene Göre Dağılımına İlişkin Bulgular}

Araştırmanın beşinci sorusu medya okuryazarlığı alanında tamamlanan lisansüstü tezlerin hangi yöntem ve desenleri kullandığının belirlenmesine ilişkindir. Lisansüstü tezlerin yöntem ve desene göre dağılımı Tablo 5'te verilmiştir. 
Tablo 5

Lisansüstü Tezlerin Yöntem ve Desene Göre Dă̆ılımı

\begin{tabular}{|c|c|c|c|c|}
\hline Yöntem & Desen & & $f$ & $\%$ \\
\hline \multirow[t]{4}{*}{ Nicel } & & Betimsel tarama & 15 & 28.3 \\
\hline & & İlişkisel tarama & 6 & 11.3 \\
\hline & & Deneysel çalışması & 3 & 5.7 \\
\hline & & Ara toplam & 24 & 45.3 \\
\hline \multirow[t]{5}{*}{ Nitel } & Etkileşimli & Eylem araştırması & 2 & 3.8 \\
\hline & & Durum çalışması & 6 & 11.3 \\
\hline & Etkileşimsiz & Kavramsal çalışma & 6 & 11.3 \\
\hline & & Teorik analiz (alanyazın taraması) /Doküman analizi & 8 & 15.1 \\
\hline & & Ara toplam & 22 & 41.5 \\
\hline Karma & & & 7 & 13.2 \\
\hline Toplam & & & 53 & 100 \\
\hline
\end{tabular}

Lisansüstü tezlerin en çok nicel yöntemleri kullandığı görülmektedir (\%45.3). Nicel yöntemlerden en çok betimsel tarama deseninin benimsendiği belirlenmiştir (\%28.3). Nitel yöntemleri kullanan tezlerin oranı da nicel çalışmalara oldukça yakındır (\%41.5). Nitel yöntemlerden en sık kullanılan desen ise alanyazın taraması ve doküman analizidir (\%15.1). Tablo 5 'te görüldüğü gibi karma yöntem kullanılan tezlerin oranı oldukça düşüktür (\%13.2) ve karma yöntem benimseyen lisansüstü tezlerde desen belirtilmediği saptanmıştır.

\section{Medya Okuryazarlığı Alanında Yapılmış Olan Lisansüstü Tezlerin Kullanılan Veri Toplama Tekniklerine Göre Dağılımına İlişkin Bulgular}

Tablo 6

Lisansüstü Tezlerin Kullanılan Veri Toplama Tekniklerine Göre Dağılımı

\begin{tabular}{lcc}
\hline Veri toplama tekniği & $f$ & $\%$ \\
\hline Ölçek & 20 & 29.5 \\
Görüşme & 13 & 19.5 \\
Doküman incelemesi & 13 & 19.5 \\
Anket & 12 & 18 \\
Değerlendirme formu & 3 & 4.5 \\
Gözlem & 3 & 4.5 \\
Öğrenci günlüğü & 1 & 1.5 \\
Facebook paylaşımı & 1 & 1.5 \\
Başarı testi & 1 & 1.5 \\
Toplam & 67 & 100 \\
\hline
\end{tabular}


Araştırmanın altıncı sorusu kapsamında, incelenen lisansüstü tezlerin kullanılan veri toplama tekniklerine göre dağılımı Tablo 6'da verilmiştir. Verilerin analizinde kavramsal araştırmalarda veri toplamada doküman kullanmış olarak kabul edilmiştir.

Tablo 6'da görüldüğü üzere en sık kullanılan veri toplama tekniği ölçek yoluyla veri toplamadır (\%29.5). Ölçek ve anket birlikte değerlendirildiğinde bu oran 47.5 'e yükselmektedir. Nitel çalışmalarda ise en sık kullanılan veri toplama tekniği görüşme ve doküman incelemesidir (\%19). Veri toplama süreçlerinde başarı testi, Facebook paylaşımıve öğrenci günlüğü kullanan sadece birer lisansüstü tez vardır.

\section{Medya Okuryazarlığı Alanında Yapılmış Olan Lisansüstü Tezlerin Veri Analiz Tekniklerine Göre Dağılımına İlişkin Bulgular}

Medya okuryazarlığı alanında yapılmış lisansüstü tezlerin verilerin analizinde kullanmış oldukları tekniklere göre dağılımı Tablo 7'de verilmiştir.

Tablo 7

Lisansüstü Tezlerin Veri Analiz Tekniklerine Göre Dă̆glımı

\begin{tabular}{|c|c|c|c|}
\hline Veri analiz tekniği & $f$ & $\%$ (teknikler) & $\begin{array}{c}\% \\
\text { (tezler) }\end{array}$ \\
\hline Betimsel istatistikler (f, \%, ss, X) & 31 & 23.8 & 58.4 \\
\hline t testi & 23 & 17.7 & 43.3 \\
\hline Anova & 20 & 15.4 & 37.7 \\
\hline Betimsel analiz (nitel) & 16 & 12.3 & 30.1 \\
\hline İçerik analizi (nitel) & 10 & 7.7 & 18.8 \\
\hline Ki-kare & 9 & 6.9 & 16.9 \\
\hline Korelasyon & 6 & 4.6 & 11.3 \\
\hline Mann Whitney U & 4 & 3.2 & 7.5 \\
\hline Kruskal Wallis & 3 & 2.3 & 5.6 \\
\hline Göstergebilimsel analiz & 2 & 1.5 & 3.7 \\
\hline Manova & 2 & 1.5 & 3.7 \\
\hline Regresyon & 2 & 1.5 & 3.7 \\
\hline Mancova & 1 & .8 & 1.8 \\
\hline Kukla kodlama & 1 & .8 & 1.8 \\
\hline Toplam & 130 & 100 & \\
\hline
\end{tabular}

Lisansüstü tezlerde birden çok veri analizi tekniği kullanıldığı ve en çok betimsel istatistiklerden yararlanıldığı saptanmıştır (\%58.4). Nicel verilerin analizinde en s1k kullanılan analiz yöntemleri t testi ve Anova gibi fark testleridir (\%81). Nitel verilerin analizlerinde ise en s1k betimsel analiz yöntemine başvurulmuştur (\%30.1). Kukla kodlama (1), Mancova (1), Regresyon (2), Manova (2) ve Göstergebilimsel analiz (2) en az kullanılan yöntemler olmuştur. 


\section{Medya Okuryazarlığı Alanında Yapılmış Olan Lisansüstü Tezlerin Örnekleme Yöntemlerine Göre Dağılımına İlişkin Bulgular}

Tablo 8 medya okuryazarlığı alanındaki lisansüstü tezlerin tercih ettikleri örnekleme yöntemlerine göre dağılımını göstermektedir.

Tablo 8

Lisansüstü Tezlerin Örnekleme Yöntemlerine Göre Dağılımı

\begin{tabular}{lll}
\hline Örnekleme Yöntemi & $f$ & $\%$ \\
\hline Belirtilmemiş & 14 & 5.2 \\
Tesadüfi örnekleme & 13 & 22.4 \\
Örneklem yok & 11 & 19 \\
Uygun örnekleme & 5 & 8.6 \\
Ölçüt örnekleme & 4 & 6.9 \\
Tabakalı örnekleme & 4 & 6.9 \\
Amaçlı örnekleme & 3 & 5.2 \\
Maksimum çeşitlilik & 2 & 3.4 \\
Küme örnekleme & 1 & 1.7 \\
Sistematik rassal & 1 & 1.7 \\
\hline Toplam & 58 & 100 \\
\hline
\end{tabular}

14 lisansüstü tezde örnekleme yönteminin rapor edilmediği saptanmıştır. Kavramsal çalışmalarda ise örneklem yer almamaktadır. Yapılan incelemede tezlerde en sık kullanılan örnekleme yönteminin tesadüfi örnekleme olduğu belirlenmiştir (\%22.4). Onu, uygun örnekleme (\%8.6), ölçüt örnekleme (\%6.9) ve tabakalı örnekleme (\%6.9) takip etmektedir. Küme örnekleme ve sistematik rassal örnekleme yalnızca birer lisansüstü tezde kullanılmıştır.

\section{Medya Okuryazarlığı Alanında Yapılmış Olan Lisansüstü Tezlerin} Örneklem Türüne Göre Dağılımına İlişkin Bulgular

Çalışmanın son araştırma sorusu, medya okuryazarlığı alanında yapılan lisansüstü tezlerin yer verdikleri örneklem türüne göre nasıl bir dağılım gösterdiğine ilişkindir. İlgili bulgular Tablo 9'da sunulmuştur.

İncelenen lisansüstü tezlerde en s1k başvurulan örneklem türünün ortaokul öğrencileri olduğu belirlenmiştir (\%34.4). Bu durum eğitim sisteminde ortaokul düzeyinde seçmeli medya okuryazarlığı dersinin yer almasının bir neticesi olabilir. Ortaokul öğrencilerini öğretmen adayları takip etmektedir (\%16.4). Diğer yandan, en az çalışılan örneklem grubunun veliler (\%6.6), lise öğrencileri (\%3.3) ve uzmanlar (\%1.6) olduğu tespit edilmiştir. 
Tablo 9

Lisansüstü Tezlerin Örneklem Türüne Göre Dă̆glımı

\begin{tabular}{llc}
\hline Örneklem türü & $\mathrm{f}$ & $\%$ \\
Ortaokul öğrencisi & 21 & 34.4 \\
Örneklem yok & 11 & 18 \\
Öğretmen adayı & 10 & 16.4 \\
Öğretmen & 7 & 11.5 \\
Doküman & 5 & 8.2 \\
Veli & 4 & 6.6 \\
Lise öğrencisi & 2 & 3.3 \\
Uzman & 1 & 1.6 \\
Toplam & 61 & 100 \\
\hline
\end{tabular}

\section{Sonuç ve Tartışma}

$\mathrm{Bu}$ araştırmada, medya okuryazarlığı alanında gerçekleştirilen lisansüstü tezler tezin tamamlandığı yıl, üniversite, bilim dalı, tezlerde yer verilen konu alanı, yöntem, desen, veri toplama tekniği, veri analiz tekniği, örnekleme yöntemi ve örneklem türü değişkenleri açısından bir içerik analizine tabi tutulmuştur. Bu analiz neticesinde medya okuryazarlığı alanında tamamlanan lisansüstü çalışmalarda araştırma eğilimlerini belirlemek ve yeni yapılacak araştırmalara yol gösterici olmak amaçlanmıştır.

Yapılan analiz neticesinde, Maden, Maden ve Banaz'ın (2017) çalışması ile de paralel olarak, medya okuryazarlığı alanında gerçekleştirilen lisansüstü tezlerin 2007 yılında başladığı, sayılarının giderek arttığ tamamlandığı belirlenmiştir. En çok lisansüstü tezin 2013 yılında tamamlanmış olduğu bulgusu medya okuryazarlığı alanındaki diğer çalışmalar için de geçerlidir. Kıncal \& Korkmaz (2015) medya okuryazarlığı alanında yayınlanan makaleleri incelemiş ve en çok sayıda makalenin 2013 yılında yayınlandığını belirlemiştir. Altun (2014) ise medya okuryazarlığı alanındaki bütün yayınların bibliyografyasını çıkardığı çalışmasında bu alandaki yayınların 2007 itibari ile hızla artmaya başladığını ve en çok sayıda yayının 2013 yılında yapıldığını saptamıştır. 2007 yılında yayınların hızla artmaya başlaması ve 2007 yılında ilk lisansüstü tezin tamamlanmış olması Türkiye'de medya okuryazarlığı çalışmalarının 2004 yılında resmi anlamda başlaması (Altun, 2009) ve 2006-2007 öğretim yılında ortaokul düzeyinde seçmeli medya okuryazarlığı dersinin başlaması ile medya okuryazarlığı alanına akademik ilginin artması ile açıklanabilir.

Araştırma bulgularına göre en çok sayıda tez Çanakkale Onsekiz Mart Üniversitesi'nde yapılmıştır. 18 üniversitede ise sadece birer tez yapılmıştır ve bu tezlerin sadece iki tanesi doktora tezidir. Bu bulgu üniversitelerde bu alanda lisansüstü düzeyde araştırmaların sınırlı düzeyde gerçekleştirildiğini göstermektedir. Çanakkale Onsekiz Mart Üniversitesi'nde üç yüksek lisans, beş doktora tezinin, Gazi Üniversitesi'nde dört yüksek lisans, üç doktora tezi ve Atatürk Üniversitesi'nde altı yüksek lisans, bir doktora tezinin tamamlanmış olması, bu üniversitelerin medya okuryazarlığı alanında yoğun çalışmalar yürüttüğünü göstermektedir. Diğer yandan, en çok sayıda lisansüstü tez gazetecilik ve radyo $T V$ ve sinema bölümlerinde gerçekleştirilmiştir. Medya okuryazarlığının bu bölümlerin doğrudan çalışma alanları 
olması nedeniyle bu beklenilen bir sonuçtur. Bununla birlikte, eğitim bilimleri ile ilişkili bölümler bir arada değerlendirildiğinde en çok sayıda lisansüstü tezin bu alanda yapıldığı belirlenmiştir. Bu durum eğitim bilimleri alanında ve öğretmenlik alanlarında medya okuryazarlığının ilgi gösterilen bir alan olduğunu ortaya koymaktadır.

Medya okuryazarlığı alanındaki lisansüstü tezlerin çalıştığı konular değerlendirildiğinde, en çok sayıda tezin medya okuryazarlığı eğitiminin çeşitli değişkenler üzerindeki etkisinin belirlenmesi üzerine gerçekleştirildiği saptanmıştır. Bu konuyu medya okuryazarlığı düzey belirleme ve görüş, algı ve tutumları belirleme konuları izlemiştir. Bu bulgu Banaz, Banaz ve Maden'in (2017) bulguları ile uyum gösterirken Kıncal ve Korkmaz'ın (2015) bulguları ile uyum göstermemektedir. Kıncal ve Korkmaz (2015) medya okuryazarlığı alanındaki makalelerin daha çok farklı ülkelerdeki uygulamaların incelenmesine ve disiplinler arası çalışmalara yoğunlaştığını belirlemişlerdir. Medya okuryazarlığı konusundaki bütün yayınlara bakıldığında ise teorik çalışmaların çoğunlukta olduğu görülmektedir (Altun, 2014).

Medya okuryazarlığı alanındaki lisansüstü tezlerde en çok nicel yöntemler tercih edilmekle beraber nitel yöntemlerin kullanılma sıklığı da nicel yöntemlere oldukça yakındır. Karma yöntemler ise çok az oranda kullanılmıştır ve karma yöntem kullanılan lisansüstü tezlerde ilgili desenlerin raporlanmadığı belirlenmiştir. Medya okuryazarlığ alanındaki makalelerin de benzer bir durumda olduğu görülmektedir. Makalelerin sadece \%3'ü karma yöntem kullanılmıştır ve makalelerin \%47'si alanyazın derleme çalışmalarından oluşmaktadır (Kıncal \& Korkmaz, 2015). Nicel yöntemlerin medya okuryazarlığı dışındaki farklı alanlarda yapılan çalışmalarda da en sık kullanılan yöntemler olduğu çeşitli araştırma eğilimlerini belirlemeye dönük inceleme çalışmalarında belirlenmiştir (Küçükoğlu \& Ozan, 2013; Ozan \& Köse, 2014; Selçuk vd., 2014). Eğitim teknolojisi (Bozkaya, Aydın \& Kumtepe, 2012; Hrastinski \& Keller, 2007), okul öncesi öğretmenliği (Yılmaz \& Altınkurt, 2012), eğitim araştırmaları (Göktaş vd., 2012) gibi alanlarda yapılan araştırma eğilimlerini belirleme çalışmalarında nicel yöntemlerin daha sık kullanıldığı belirlenmiştir. Karma yöntemler de farklı alanlarda en az kullanılan yöntem türü olarak belirlenmiştir (Eğmir, Erdem, \& Koçyiğit, 2017; Gülbahar \& Alper, 2009). Her ne kadar nicel yöntemlerin bazı üstünlükleri olsa da nitel ve özellikle karma yöntemleri kullanan daha fazla sayıda araştırmaya ihtiyaç vardır (Eğmir, Erdem, \& Koçyiğit, 2017).

Lisansüstü tezlerin yöntem bölümlerine ilişkin alt bulgulara göre, nicel yöntem kullanan tezlerde en çok ölçek ve anket; nitel yöntem kullanan tezlerde ise en çok görüşme ve doküman incelemesi kullanılmıştır. Nicel çalışmalarda en sık olarak ölçek ve anketlerin kullanılması farklı alanlardaki çalışmalarda da benzer şekilde belirlenmiştir (Selçuk vd., 2014; Şimşek vd., 2008; Yılmaz \& Altınkurt, 2012). Diğer yandan, medya okuryazarlığı alanındaki lisansüstü tezlerde verilerin analizinde en çok betimsel istatistiklerden yararlanıldığ nitel verilerin analizinde ise en sik betimsel analiz yöntemine başvurulduğu belirlenmiştir. Bu bulgular alanyazındaki diğer alanlardaki inceleme çalışmaları ile uyum göstermektedir (Eğmir, Erdem, \& Koçyiğit, 2017; Turan vd., 2014; Varışoğlu vd., 2013).

Örnekleme ilişkin incelemelerde ise, 14 tezde örnekleme yöntemine yer verilmediği, en sık kullanılan örnekleme yönteminin tesadüfi örnekleme olduğu ve onu uygun örnekleme, ölçüt örnekleme ve tabakalı örneklemenin takip ettiği belirlenmiştir. 
Diğer yandan, tezlerde en sık başvurulan örneklem grubunun ortaokul öğrencileri olduğu ve o grubu öğretmen adaylarının takip ettiği belirlenmiştir. En çok bu iki örneklem grubundan yararlanıldığı bulgusu medya okuryazarlığı alanındaki makaleler için de geçerlidir (Kıncal \& Korkmaz, 2015). Seçmeli medya okuryazarlığg dersinin eğitim sisteminde sadece ortaokul düzeyinde verilmesi en s1k başvurulan örneklem grubunun ortaokul öğrencileri olmasını açıklamaktadır. Öğretmen adaylarının ileride konunun paydaşı olacak olmaları ve en çok tezin eğitim bilimleri alanında yapıldığı düşünüldüğünde, araştırmacılar için daha kolay ulaşılabilir olmaları öğretmen adaylarının en sık başvurulan ikinci örneklem grubu türü olmasını açıklayabilir. Ancak Altun'a (2014) göre medya okuryazarlığının yaşam boyu bir beceri olduğu düşünülürse, araştırmaların okul öncesi, yükseköğretim ve yetişkin eğitimi gibi kitlelere de yönelmesinin bir gereklilik olduğunu düşünmektedir.

\section{Öneriler}

Medya okuryazarlığı alanındaki lisansüstü tezlerin özelliklerinin incelendiği bu araştırmada ulaşılan sonuçlara dayalı olarak bazı öneriler geliştirilebilir. Medya okuryazarlığı alanındaki çalışmalarda düzey, etki ve alg1 belirlemenin yanı sıra medyada uyuşturucu, şiddet, siber zorbalık vb. olumsuzlukların çözümünde medya okuryazarlığının katkısı, program geliştirme, meta analiz ve uygulamalı çalışmalara yer verilmesi uygun olacaktır. Diğer yandan, tezlerde hem nicel hem de nitel yöntemlerin güçlü yanlarını bir araya getiren karma yöntemlerin tercih edilmesi uygun olacaktır. Ayrıca karma yöntemlerin desenlerinin de belirlenmesi ve desen, örnekleme yöntemi gibi hususların da raporlanması gerekmektedir. Medya okuryazarlığı alanındaki çalışmaların üzerinde çalıştıkları örneklem grupları ortaokul öğrencileri ve öğretmen adaylarının yanı sıra okul öncesinden yükseköğretime bütün eğitim kademelerindeki öğrencileri, öğretmenleri, velileri, yaşlıları ve çeşitli meslek grubu üyelerini içermelidir. Son olarak, belirli periyotlarla bu alanda yapılan çalışmaların sistematik incelemelerinin yapılması alanın daha net bir resmini ortaya koymak açısından önem taşımaktadır. Bu araştırmanın medya okuryazarlığı alanında çalışma yapacak araştırmacılara yol gösterici olmasi umulmaktadır. 


\section{Summary}

Purpose and Significance: The rapid advances in information and communication technologies and media have transformed individuals' lives in the twenty first century (Kellner \& Share, 2007). Media is located in the center of individuals' lives who now live in a digital balloon (Pérez Tornero \& Varis, 2010). New media tools and platforms have gained widespread access thanks to the relative fall in the prices of them lately (Erdem, 2018) and this prevalence of media effects requires new skills and competences. Individuals need to gain these skills that are named as twenty first century skills (Günüç, Odabaşı \& Kuzu, 2013). Though there are different classifications as to what these skills are, media literacy is agreed upon by many as one of the most important twenty first century skills (Deveci \& Çengelci, 2008; Finegold \& Notabartolo, 2008).

Defined as the ability access, analyze, evaluate and communicate various media messages in a variety of forms (Aufderheide, 1993), media literacy has been researched in diverse fields such as fine arts, performance arts, history, psychology, sociology and education across the world (Hobbs, 1998). Meanwhile in Turkey, media literacy has a delayed start compared to other countries (Som \& Kurt, 2012). Media literacy studies commenced in Turkey after the year 2000 (Önal, 2007) and gained popularity after the introduction of optional media literacy course in secondary schools in the academic year of 2006-2007. As of this date, studies on media literacy increased in great amounts and more than three million students did media literacy course. The increase in articles, conference presentations, books and dissertations in media literacy field suggests the academic interest lately (Altun, 2014).

Reviewing the academic studies in media literacy field and thereby identifying research trends are of high significance. As scientific studies, which affect policies and implications in scientific area and serve as a guide for practitioners (Karadağ, 2009), move on based on other scientific studies, reviewing them is a must (Gülbahar \& Alper, 2009). Reviewing studies and identification of research trends in a scientific field enable viewing changes and advances in that field (Yıldız, Melekoğlu \& Paftal1, 2016). Therefore, reviewing studies in media literacy field and identification of research trends would provide an insight for the media literacy field and guide future studies. Altun (2014) created a bibliography of media literacy publications, Kıncal \& Korkmaz (2015) reviewed articles on media literacy and Maden, Maden \& Banaz (2017) examined dissertations on media literacy from the aspects of aim, year and results. A more detailed examination on dissertations on media literacy is needed as 65 dissertations were completed in the last ten years, which puts forth a growing academic literature. To fill this gap, this study aims to review postgraduate dissertations in media literacy field completed in Turkey with respect to completion year, university, department, topic, method, design, data collection technique, data analysis technique, sampling method and sample type variables.

Methods: This is a qualitative, descriptive literature review study aiming to review postgraduate dissertations in media literacy field. Literature review studies are evaluations of material that has already been published (APA, 2010). In the study, data was collected via document analysis method. Document analysis includes analysis of 
written materials such as official publications, reports, records, open-ended responses to questionnaires and surveys (Patton, 2002).

The sample in this study consists of postgraduate dissertations on media literacy that were completed as of July 2017 and accessible on the website of Council of Higher Education Thesis Center. 65 dissertations, 12 of which were not available for full access, were downloaded and 39 master's dissertations and $14 \mathrm{PhD}$ dissertations were analyzed via content analysis method using a dissertation review form created by the researcher.

Results: The results of the study reveal that the first dissertation was completed in 2007. Between 2007 and July 2017, 65 dissertations were completed. Of these dissertations, 48 are Master's dissertations and 17 are $\mathrm{PhD}$ dissertations. The highest number of dissertations was completed in 2013 (20\%). Only one dissertation was completed in 18 universities and the highest number of dissertations was completed in Çanakkale Onsekiz Mart University (12.3\%), which is followed by Gazi University (10.8\%) and Atatürk University (10.8\%). The dissertations were carried out in 17 departments and the highest number is in the departments of journalism (15.4\%) and radio TV and cinema (13.8\%). However, when departments related to educational sciences are combined, the highest number is in these departments $(56.8 \%)$. The topics of the dissertations were grouped under eight categories. The most investigated topics are identification of the effects of media literacy education and participants' levels of media literacy. The most frequently used methods in the dissertations are quantitative methods (45.3\%) and, qualitative methods (41.5\%) and mixed methods (13.2\%) follow it. Of the quantitative methods, the most used design is descriptive survey (28.3\%) while literature review designs $(15.1 \%)$ are mostly preferred in qualitative methods. The designs of the mixed method studies were not reported. The most resorted data collection techniques include scales/questionnaires (47.5\%), interviews (19.5\%) and document analysis (19.5\%). Achievement test, Facebook posts and student journal were each used in one study. The most preferred data analysis techniques are descriptive statistics (58.4\%). Tests of difference such as t-test or ANOVA (81\%) were performed in quantitative studies while descriptive analysis (30.1\%) is preferred most in qualitative studies. The most used sampling methods include random sampling (22.4\%) and convenience sampling (8.6\%). 11 theoretical dissertations do not include a sample; however, 14 dissertations do not report sampling method though one is used. The most resorted sample types include secondary school students $(34.4 \%)$ and prospective teachers $(16.4 \%)$.

Discussion and Conclusions: The findings that the first dissertation on media literacy was completed in 2007, they increased in number thereafter and the highest number of dissertations was completed in 2013 are compatible with the findings of other review studies on media literacy in Turkey. Kincal \& Korkmaz (2015) reviewed articles on media literacy and found out that the highest number of articles was also published in 2013. In the bibliographic study by Altun, 2014, it was put forth that all publications on media literacy including dissertations, articles, books, conference presentations and so on gathered pace after 2007 and the highest number of publications was in 2013. These findings may be related to the fact that media literacy officially came up in 2004 in Turkey (Altun, 2009) and the introduction of media literacy course in secondary schools 
in 2006 led academic interest in this field. The findings of second research question put forth that though a few universities have expertise in media literacy, only one dissertation was completed in 18 universities, most of which were master's dissertations. More than half of the dissertations were completed in the departments related to educational sciences. This case gives a hint for the academic interest on media literacy in educational sciences and preservice teacher education fields. The most investigated topics in the dissertations were identification of the effects of media literacy education and participants' levels of media literacy. Though this finding is in parallel with Banaz, Banaz \& Maden (2017), it contradicts with Kincal \& Korkmaz (2015). They identified that articles on media literacy mostly addressed examination of media literacy practices in other countries. On the other hand, theoretical studies predominate regarding all publications in the field (Altun, 2014).

The most frequently used methods in the dissertations are quantitative methods and, qualitative methods and mixed methods follow it. This trend is in the same fashion in articles on media literacy. Only 3\% of the articles used mixed methods (Kincal \& Korkmaz, 2015). The finding that quantitative methods are the most frequently used methods is also compatible with other review studies on other fields (Bozkaya, Aydin \& Kumtepe, 2012; Hrastinski \& Kellner, 2007; Küçükoğlu \& Ozan, 2013; Ozan \& Köse, 2014; Selçuk vd., 2014). Mixed methods are also the least used methods in other fields (Eğmir, Erdem \& Koçyiğit, 2017; Gülbahar \& Alper, 2009). Though quantitative methods have some advantages, studies in qualitative and mixed methods in particular are needed (Eğmir, Erdem \& Koçyiğit, 2017). The finding that scales/questionnaires are the most frequently used data collection techniques in quantitative studies are in parallel with review studies on other fields (Selçuk vd., 2014; Şimşek vd., 2008); Y1lmaz \& Altınkurt, 2012). The same is true for descriptive analysis in qualitative studies (Eğmir, Erdem \& Koçyiğit, 2017; Turan vd., 2014; Varışoğlu vd., 2013). The most resorted sample types in the dissertations include secondary school students and prospective teachers. This finding is also valid for articles on media literacy. The only media literacy education opportunity is provided for secondary school students in Turkey. This explains the majority of secondary school students as participants. Besides, prospective teachers are supposed to be part of this education in the future and they are relatively easy to access for researchers given the fact that the majority of dissertations were carried out in departments related to educational sciences and preservice teacher education. However, Altun (2014) asserts that media literacy is a lifelong skill and studies should also address pre-school education, higher education and adult education.

This study which aims to identify research trends in media literacy field via a detailed content analysis of postgraduate dissertations on media literacy offer some recommendations based on the findings. Studies on media literacy should also investigate topics such as the contribution of media literacy education in the solving the problems of drugs, aggression, cyberbullying and so on in media, curriculum development, meta-analysis and practical issues besides identification of the effects of media literacy education and participants' levels of media literacy. Furthermore, mixed method studies which combine advantages of quantitative and qualitative methods should be preferred. The design of the mixed methods should also be reported in the publications. Beside secondary school students and prospective teachers, studies should also address all levels of students from pre-school level to higher education, teachers, 
parents, elders and people from different occupational groups. Finally, systematic reviews of studies on media literacy field should be carried out periodically for a clear understanding of the field. This study is expected to guide future studies on media literacy. 


\section{Kaynakça}

Aktı, S. (2011). Illköğretim sekizinci sınıf öğrencilerinin medya okuryazarlı̆̆ ile sosyal beceri düzeyleri arasındaki ilişkinin belirlenmesi (Yayımlanmamış Yüksek Lisans Tezi). Frrat Üniversitesi, Elazığ.

Altun, A. (2009). Eğitim bilim açısından seçmeli medya okuryazarlığı dersi programına eleştirel bir yaklaşım. Ahi Evran Üniversitesi Eğitim Fakültesi Dergisi, 10(3), $97-$ 109.

Altun, A. (2010). Medya okuryazarlı̆̆ının sosyal bilgiler programlarıyla ilişskilendirilmesi ve ögretimi (Yayımlanmamış Doktora Tezi). Gazi Üniversitesi, Ankara.

Altun, A. (2014). Medya okuryazarlığı eğitimine yönelik Türkçe yayınlar: Bir bibliyografya denemesi. Ordu Üniversitesi Sosyal Bilimler Araştırmaları Dergisi, 9, 5-15.

APA. (2010). Publication manual of the American Psychological Association. Washington DC: American Psychological Association.

Apak, Ö. (2008). Türkiye, Finlandiye ve İlanda ilköğretim programlarının medya okuryazarlı̆̆ı ĕgitimi açısından incelenmesi (Yayımlanmamış Yüksek Lisans Tezi). Kocaeli Üniversitesi, Kocaeli.

Ardıç, E. (2016). Medya okuryazarlığı ile ilgili lisansüstü çalışmaların karşılaştırmalı incelenmesi: Türkiye, ABD ve Kanada Örneği (Yayımlanmamış Yüksek Lisans Tezi). Abant İzzet Baysal Üniversitesi, Bolu.

Aslan, H. (2009). Medya okuryazarlı̆̆ının görsel kültür ve sanat eğitimi ekseninde çözümlenmesi (Yayımlanmamış Yüksek Lisans Tezi). Ondokuzmayıs Üniversitesi, Samsun.

Aufderheide, P. (1993). Media Literacy: A report of the national leadership conference on media literacy. Washington DC: Aspen Institute.

Aydemir, S. (2013). Ortaokul 8. sını ögrrencilerinin medya okuryazarlık düzeylerinin çeşitli değişkenler açısından incelenmesi (Yayımlanmamış Yüksek Lisans Tezi). Eskişehir Osmangazi Üniversitesi, Eskişehir.

Bacaksız, T. (2010). Medya okuryazarlı̆̆ dersinde gazete ve dergi kullanımı: İzmir'de medya okuryazarlı̆̆l dersinin ögrencilerin gazete ve dergi okuma alışkanlıklarına olan etkisi (Yayımlanmamış Yüksek Lisans Tezi). Gazi Üniversitesi, Ankara.

Bakan, U. (2010). Illköğretim medya okuryazarlı̆̆ dersinin öğrencilerin eleştirel düşünme becerilerine etkisi (Yayımlanmamış Yüksek Lisans Tezi). Atatürk Üniversitesi, Erzurum.

Baş, G. (2015). Eleştirel sosyal medya okuryazarlı̆̆ bağlamında yeni medyada imaj, görüntü ve beden sunumu (Yayımlanmamış Yüksek Lisans Tezi). Ege Üniversitesi, İzmir.

Bilici, İ. E. (2011). Türkiye'de ortaöğretimde medya okuryazarlı̆̆ı dersi için bir model önerisi (Yayımlanmamış Doktora Tezi). Erciyes Üniversitesi, Kayseri.

Bloor, M. \& Wood, F. (2006). Keywords in qualitative methods: A vocabulary of research concepts. Londra: Sage. 
Bozkaya, M., Aydın, İ. E. \& Kumtepe, E. G. (2012). Research trends and issues in educational technology: a content analysis of TOJET (2008-2011). The Turkish Online Journal of Educational Technology, 11(2), 264-277.

Bütün, E. (2010). Medya okuryazarliğl dersine ilişkin ögrretmen, ögrenci ve veli görüşleri (Samsun ili örneği) (Yayımlanmamış Yüksek Lisans Tezi). Ondokuz Mayıs Üniversitesi, Samsun.

Çakmak, E. (2010). Ingiltere ve Türkiye'deki ilköğretim medya okuryazarlı̆̆ı ĕgitimi program ve uygulamalarının karşılaştırmalı olarak incelenmesi (Yayımlanmamış Doktora Tezi). Abant İzzet Baysal Üniversitesi, Bolu.

Çelik, M. (2008). Egemen ideolojinin bir aracı olarak medya ve eleştirel farkındalığın gerekliliği: Medya okuryazarlı̆̆ı (Yayımlanmamış Doktora Tezi). Marmara Üniversitesi, İstanbul.

Çelik, T. (2011). Sosyal bilgiler öğretmen adaylarının çok kültürlü bakış açısı geliştirmelerinde medya okuryazarlığl dersinin rolüne ilişkin bir çalışma (Yayımlanmamış Yüksek Lisans Tezi). Pamukkale Üniversitesi, Denizli.

Çetinkaya, S. (2008). Bilinçli medya kullanıcıları yaratma sürecinde medya okuryazarlığının önemi (Yayımlanmamış Yüksek Lisans Tezi). Ankara Üniversitesi, Ankara.

Çiçek, E. (2013). Medya okuryazarlık düzeyi ile medya kullanımı arasındaki ilişki: Illetişim meslek lisesi öğrencileri üzerine bir alan araştırması (Yayımlanmamış Yüksek Lisans Tezi). Marmara Üniversitesi, İstanbul.

Çinelioğlu, G. (2013). Sosyal bilgiler öğretmen adaylarının medya okuryazarlı̆̆ dersine yönelik tutumlarının incelenmesi (Yayımlanmamış Yüksek Lisans Tezi). Balıkesir Üniversitesi, Balıkesir.

Deveci, H. \& Çengelci, T. (2008). Sosyal bilgiler öğretmen adaylarından medya okuryazarlığına bir bakış. Yüzüncü Yıl Üniversitesi Eğitim Fakültesi Dergisi, 5(2), 25-43.

Eğmir, E., Erdem, C. \& Koçyiğit, M. (2017). Trends in educational research: A content analysis of the studies published in international journal of instruction. International Journal of Instruction, 10(3), 277-294.

Erdem, C. (2018). Medya okuryazarlı̆̆ ve ögrretmen ĕgitimi: Öğretmen adayları için bir ögretim programı tasarısı. Ankara: Pegem Akademi.

Ertek, Z. Ö. (2013). Sınıf öğretmenlerinin medya okuryazarlık düzeyleri (Yayımlanmamış Yüksek Lisans Tezi). Gazi Üniversitesi, Ankara.

Finegold, D. \& Notabartolo, A. S. (2008). 21st century competencies and their impact: an interdisciplinary literature review. https://www.hewlett.org/library/21st-centurycompetencies-impact-interdisciplinary-literature-review/ (Erişim tarihi: 12.10.2017)

Göktaş, Y., Hasançebi, F., Varışoğlu, B., Akçay, A., Bayrak, N., Baran, M., \& Sözbilir, M. (2012). Türkiye'deki eğitim araştırmalarındaki eğilimler: bir içerik analizi. Kuram ve Uygulamada Ĕ̈itim Bilimleri, 12(1), 443-460.

Görmez, E. (2014). Ortaokul öğrencilerinin medya okuryazarlı̆̆ düzeyleri (Yayımlanmamış Doktora Tezi). Atatürk Üniversitesi, Erzurum. 
Gülbahar, Y., \& Alper, A. (2009). A content analysis of the studies in instructional technolohies area. Ankara University Journal of Faculty of Educational Sciences, 42(2), 93-111.

Güner, F. (2011). İlköğretim II. kademe ögrencilerinin televizyon dizilerindeki mesajları algılamalarında medya okuryazarlı̆̆ının etkisi (Yayımlanmamış Yüksek Lisans Tezi). Çanakkale Onsekiz Mart Üniversitesi, Çanakkale.

Günüç, S., Odabaşı, H. F. \& Kuzu, A. (2013). 21. yüzyıl öğrenci özelliklerinin ögretmen adayları tarafından tanımlanması: Bir Twitter uygulaması. Eğitimde Kuram ve Uygulama, 9(4), 436-455.

Hobbs, R. (1998). The seven great debates in the media literacy movement. Journal of Communication, 48(1), 16-32.

Hobbs, R. \& Frost, R. (2003). Measuring the acquisition of media-literacy skills. Reading Research Quarterly, 38(3), 330-355.

Hrastinski, S. \& Keller, C. (2007). An examination of research approaches that underlie research on educational technology: a review from 2000 to 2004. Journal of Educational Computing Research, 36(2), 175-190.

İlhan, E. (2014). Medya metinlerinin bilinçli okunmasında medya okuryazarlı̆̆ dersinin etkisi üzerine bir analiz (Ankara ili örneği) (Yayımlanmamış Yüksek Lisans Tezi). Gazi Üniversitesi, Ankara.

İnan, T. (2010). Öğretmen adaylarının medya okuryazarlık düzeyleri ve medya okuryazarlığına ilişkin görüşleri (Yayımlanmamış Yüksek Lisans Tezi). Dumlupınar Üniversitesi, Kütahya.

İnan, T. (2013). Medya okuryazarlı̆̆ sürecinde medya, çocuk ve ebeveyn ilişkisi: Ortaokul ögrencilerinin ve ebeveynlerinin televizyon ve internet kullanımlarına ilişkin tutum ve davranışlarının incelenmesi (Yayımlanmamış Doktora Tezi). Dumlupınar Üniversitesi, Kütahya.

Karadağ, E. (2009). A thematic analysis on doctoral dissertations made in the area of education sciences. Ahi Evran Üniversitesi Eğitim Fakültesi Dergisi, 10(3), 75-87.

Karakoç, E. (2013). Medya okuryazarlı̆̆ dersini alan öğrencilerin medyaya bakışı: Kayseri örneği (Yayımlanmamış Yüksek Lisans Tezi). Selçuk Üniversitesi, Konya.

Karataş, A. (2008). Öğretmen adaylarının medya okuryazarlık düzeyleri (Yayımlanmamış Yüksek Lisans Tezi). Afyon Kocatepe Üniversitesi, Afyonkarahisar.

Kartal, O. Y. (2007). Ortaöğretim 10. sinıf öğrencilerinin televizyon dizilerindeki mesajları algılamalarında medya okuryazarlığ etkisi (Yayımlanmamış Yüksek Lisans Tezi). Çanakkale Onsekiz Mart Üniversitesi, Çanakkale.

Kartal, O. Y. (2013). Öğretmen adaylarının medya okuryazarlık düzeyleri ile aktif vatandaşlık bağlamında toplum yaşamına katılma düzeyleri arasındaki ilişki (Yayımlanmamış Doktora Tezi). Çanakkale Onsekiz Mart Üniversitesi, Çanakkale.

Keleş, M. (2013). Eleştirel pedagoji bağlamında medya okuryazarlı̆̆ı dersinin işleniş biçiminin incelenmesi (Yayımlanmamış Yüksek Lisans Tezi). Atatürk Üniversitesi, Erzurum. 
Keleş, S. (2009). İlköğretim medya okuryazarlı̆̆ı dersi öğretim programına ilişkin ögretmen görüşleri (Yayımlanmamış Yüksek Lisans Tezi). Abant İzzet Baysal Üniversitesi, Bolu.

Kellner, D. \& Share, J. (2007). Critical media literacy, democracy and the reconstruction of education. D. Macedo ve S. R. Steinberg (Editörler), Media Literacy: A reader içinde (ss.3-23). New York: Pater Lang Publishing.

Kıncal, R. Y. \& Korkmaz, Z. S. (2015). Türkiye'de medya okuryazarlığı üzerine bir değerlendirme. Uluslararası Ĕgitim Programları ve Öğretim Çalışmaları Dergisi, 5(10), 75-90.

Koçak, B. (2011). Illköğretim yedinci ve sekizinci sınıf öğrencilerinin medya okuryazarlığı dersine ilişkin algıları (Yayımlanmamış Yüksek Lisans Tezi). Atatürk Üniversitesi, Erzurum.

Küçükoğlu, A. \& Ozan, C. (2013). Sınıf öğretmenliği alanındaki lisansüstü tezlere yönelik bir içerik analizi. Uluslararası Avrasya Sosyal Bilimler Dergisi, 4(12), $27-$ 47.

Maden, S., Maden, A. \& Banaz, E. (2017). A content analysis regarding postgraduate theses prepared on media literacy. International Journal of Languages' Education and Teaching, 5(1), 588-605.

Masterman, L. (2005). Teaching the media. Taylor \& Francis e-Library.

Oflaz, T. (2016). Medya okuryazarlı̆̆ı dersi kapsamında öğrencilerin, medyaya bakış açılarının değerlendirilmesi: Denizli ili örneği (Yayımlanmamış Yüksek Lisans Tezi). Yaşar Üniversitesi, İzmir.

Oktay, H. T. (2013). Demokrasi kültürünü geliştirme aracı olarak medya okuryazarlı̆̆l: Türkiye uygulaması (Yayımlanmamış Yüksek Lisans Tezi). Gazi Üniversitesi, Ankara.

Ozan, C. \& Köse, E. (2014). Eğitim programları ve öğretim alanındaki araştırma eğilimleri. Sakarya University Journal of Education, 4(1), 116-136.

Önal, İ. H. (2007). Medya okuryazarlığı: kütüphanelerde yeni çalışma alanı. Türk Kütüphaneciliği, 21(3), 335-359.

Patton, M. Q. (2002). Qualitative research \& evaluation methods. Thousand Oaks: Sage Pub.

Pérez Tornero, J. M. \& Varis, T. (2010). Media literacy and new humanism. Moscow: UNESCO Institute for Information Technologies in Education.

Sadriu, S. (2009). Seçmeli medya okuryazarlı̆̆ dersi alan ilköğretim ikinci kademe ögrencilerinin ders sonu çıktılarına yönelik bir pilot araştırma (Yayımlanmamış Yüksek Lisans Tezi). İstanbul Üniversitesi, İstanbul.

Selçuk, Z., Palanc1, M., Kandemir, M. \& Dündar, H. (2014). Eğitim ve bilim dergisinde yayınlanan araştırmaların eğilimleri: içerik analizi. Ĕgitim ve Bilim, 39(173), 430453.

Semiz, L. (2013). Ortaokul öğrencilerinin medya okuryazarlığı yeterlikleri ve medya okuryazarlı̆̆ı dersini yürüten öğretmenlerin karşılaştıkları sorunlar (Yayımlanmamış Yüksek Lisans Tezi). Recep Tayyip Erdoğan Üniversitesi, Rize.

Sevim, F. (2013). Medya okuryazarlı̆̆l, toplumsal cinsiyet ve kadının medyada temsili (Yayımlanmamış Yüksek Lisans Tezi). İstanbul Ticaret Üniversitesi, İstanbul. 
Sezen, D. (2011). Katılımcı kültürün oluşumunda yeni medya okuryazarlığı: ABD ve Türkiye örnekleri (Yayımlanmamış Doktora Tezi). İstanbul Üniversitesi, İstanbul.

Solmaz, T. (2016). Yeni iletişim teknolojileri bağlamında medya okuryazarlı̆̆ (Yayımlanmamış Yüksek Lisans Tezi). Atatürk Üniversitesi, Erzurum.

Som, S. \& Kurt, A. A. (2012). Bilgisayar ve öğretim teknolojileri eğitimi bölümü öğrencilerinin medya okuryazarlık düzeyleri. Anadolu Journal of Educational Sciences International, 2(1), 104-119.

Söylemez, Y. S. (2012). Asya ve okyanusya ülkelerinde medya okuryazarlı̆̆ eğitimi: Türkiye ve Yeni Zelenda karşılaştırması (Yayımlanmamış Yüksek Lisans Tezi). Kocaeli Üniversitesi, Kocaeli.

Sur, E. (2012). İlköğretim ikinci kademe öğretmen ve öğrencilerinin medya okuryazarlı̆̆ına ilişkin görüşleri (Yayımlanmamış Yüksek Lisans Tezi). Niğde Üniversitesi, Niğde.

Şahin, M. (2012). Medya okuryazarlı̆̆ı dersi alan ve almayan ilköğretim okulu ögrencilerinin medya tüketim alışkanlıkları farklılaşması (Yayımlanmamış Yüksek Lisans Tezi). Marmara Üniversitesi, İstanbul.

Şeylan, S. (2008). Medya okuryazarlı̆̆ ders uygulamalarında dünya üzerinde görülen aksaklıklar (Yayımlanmamış Yüksek Lisans Tezi). İstanbul Kültür Üniversitesi, İstanbul.

Şimşek, A., Özdamar, N., Becit, G., Kılıçer, K., Akbulut, Y. \& Yıldırım, Y. (2008). Türkiye'deki eğitim teknolojisi araştırmalarında güncel eğilimler. Selçuk Üniversitesi Sosyal Bilimler Dergisi, 19, 439-458.

Tan, O. (2015). Medya okuryazarlı̆̆ı ĕgitimi: Öğrenci, öğretmen, aile bağlamında örnek bir araştırma (Yayımlanmamış Doktora Tezi). Akdeniz Üniversitesi, Antalya.

Tanrıkulu, F. (2014). Medya okuryazarlı̆̆ bă̆lamında çocuk dergileriyle zenginleştirilmişs Türkçe dersinin etkililiği: Bir eylem araştırması (Yayımlanmamış Doktora Tezi). Çanakkale Onsekiz Mart Üniversitesi, Çanakkale.

Tatar, İ. (2016). Öğretmen adaylarının medya okuryazarlı̆̆ ile çevrimiçi bilgi arama stratejileri arasındaki iliş̧kinin incelenmesi (Yayımlanmamış Yüksek Lisans Tezi). Anadolu Üniversitesi, Eskişehir.

Tuncel, G. (2014). Ortaokul öğrencilerinin medya okuryazarlı̆̆ına ilişkin görüşleri (Yayımlanmamış Yüksek Lisans Tezi). Marmara Üiversitesi, İstanbul.

Turan, S., Karadağ, E., Bektaş, F. \& Yalçın, M. (2014). Türkiye'de eğitim yönetiminde bilgi üretimi: kuram ve uygulamada eğitim yönetimi dergisi 2003-2013 yayınlarının incelenmesi. Kuram ve Uygulamada Ĕ̆itim Yönetimi, 20 1), 93-119.

Tutkun, T. (2013). Öğretmen adaylarının medya okuryazarlı düzeyleri ile atif vatandaşlık bileşenlerinden temsili demokrasiye, protesto ve sosyal değişime katılım düzeyi arasındaki ilişki (Yayımlanmamış Doktora Tezi). Çanakkale Onsekiz Mart Üniversitesi, Çanakkale.

Tüzel, S. (2012). Illkögrretim ikinci kademe Türkçe derslerinde medya okuryazarlı̆̆ eğitimi: Bir eylem araştırması (Yayımlanmamış Doktora Tezi). Çanakkale Onsekiz Mart Üniversitesi, Çanakkale. 
Ülker, M. (2012). Medya okuryazarlı̆̆ı dersi öğretmen kılavuz kitabının öğretim programı ile tutarlılı̆̆ının değerlendirilmesi (Yayımlanmamış Doktora Tezi). Gazi Üniversitesi, Ankara.

Varışoğlu, B., Şahin, A. \& Göktaş, Y. (2013). Türkçe eğitimi araştırmalarında eğilimler. Educational Sciences: Theory \& Practice, 13(3), 1767-1781.

Yazgan, A. D. (2013). Öğretmen adaylarının medya okuryazarlık düzeyleri ile aktif vatandaşlı̆̆a iliş̧kin demokratik değer düzeyleri arasındaki ilişki (Yayımlanmamış Doktora Tezi). Çanakkale Onsekiz Mart Üniversitesi, Çanakkale.

Yıldırım Ankaralıgil, S. (2009). Ilköğretim 6. ve 7. sınıf öğrencilerinde medya okuryazarlı̆̆l ve eleştirel düşünme üzerine bir araştırma (Yayımlanmamış Yüksek Lisans Tezi). İstanbul Üniversitesi, İstanbul. Y1ldı, V. A. (2011). Bir sosyal ögrenme aracı olarak medya ve ahlaki gelişim kuramları açısından medya okuryazarlığına eleştirel bir bakış (Yayımlanmamış Yüksek Lisans Tezi). Atatürk Üniversitesi, Erzurum.

Yıldız, N. G., Melekoğlu, M. A., \& Paftalı, A. T. (2016). Türkiye'de özel eğitim araştırmalarının incelenmesi. Elementary Education Online, 15(4), 1076-1089.

Y1lmaz, E. (2013). Sınıf öğretmeni adaylarının gazete ve dergi takip etme alışkanlıkları ile eleştirel ve medya okuryazarlık düzeyleri arasındaki ilişki (Yayımlanmamış Yüksek Lisans Tezi). Adnan Menderes Üniversitesi, Aydın.

Y1lmaz, K. \& Altınkurt, Y. (2012). An examination of articles published on preschool education in Turkey. Educational Sciences: Theory \& Practice, Özel Sayl (Sonbahar), 3227-3241.

Yördem, A. (2012). Pre-service teachers' perceptions of media literacy in the department of English language teaching in Turkey (Yayımlanmamış Yüksek Lisans Tezi). Çanakkale Onsekiz Mart Üniversitesi, Çanakkale.

This is an Open Access article distributed under the terms of the Creative CommonsAttributionNonCommercial-ShareAlike 4.0 International (CC BY-NC-SA 4.0). For further information, you can refer to https://creativecommons.org/licenses/by-nc-sa/4.0/ 